\title{
Studi Zona Nilai Tanah di Sekitar Lokasi Pembangunan Pelabuhan Internasional Kalimireng
}

\author{
Erlenda Prameswari Putri, Yanto Budisusanto, Udiana Wahyu D, Andy Dediyono \\ Jurusan Teknik Geomatika, Fakultas Teknik Sipil dan Perencanaan, Institut Teknologi Sepuluh \\ Nopember (ITS) \\ Jl. Arief Rahman Hakim, Surabaya 60111 Indonesia \\ e-mail: yanto_b@geodesy.its.ac.id,udiana@geodesy.its.ac.id, andydediyono@gmail.com
}

\begin{abstract}
Abstrak-Pelabuhan merupakan suatu pintu gerbang untuk masuk ke suatu daerah tertentu dan sebagai prasarana penghubung antar daerah, antar pulau, bahkan antar negara [2]. Pemerintah Indonesia terus mengupayakan pemanfaatan laut secara lebih baik untuk kesejahteraan rakyat terutama dari segi ekonomi. Pembangunan infrastruktur seperti pelabuhan untuk mewujudkan tol laut adalah salah satu cara pemerintah untuk memanfaatkan laut. Pembangunan Pelabuhan Internasional Kalimireng yang sedang berjalan di Kecamatan Manyar, Kabupaten Gresik adalah cara pemerintah dalam mewujudkan program tol laut. Dengan pembanguan Pelabuhan Internasional Kalimireng tersebut secara otomatis berpengaruh pada lingkungan sekitar karena menjadikan wilayah sekitar pelabuhan semakin strategis dengan potensi ekonomi yang cukup besar. Dengan perubahan wilayah yang menjadi strategis dan memiliki potensi ekonomi yang cukup besar, berimbas pada nilai tanah di wilayah tersebut. Oleh karena itu, pada penelitian ini dilakukan analisa perubahan nilai tanah di sekitar lokasi pembangunan Pelabuhan Internasional Kalimireng Penelitian ini bertempat di Kecamatan Manyar dan Bungah, Kabupaten Gresik. Penelitian ini bertujuan untuk menganalisa perubahan nilai tanah di sekitar lokasi pembangunan Pelabuhan Internasional Kalimireng. Kegiatan ini menggunakan data spasial berupa peta rencana tata ruang wilayah tentang penggunaan lahan tahun 2015, citra terkoreksi tahun 2014, dan koordinat lokasi survei harga tanah. Sedangkan data non spasial yang digunakan adalah data harga tanah hasil survei di lapangan dan data Nilai Jual Objek Pajak (NJOP) dari Dinas Pendapatan, Pengelolaan Keuangan dan Aset Daerah (DPPKAD) Kabupaten Gresik. Metode yang digunakan adalah metode pendekatan perbandingan data pasar (sales comparison approach). Penelitian ini menghasilkan Peta Zona Nilai Tanah (ZNT) 2016 dan Peta Pola Sebar Nilai Tanah 2016. Dengan dilakukannya kegiatan analisa perubahan nilai tanah secara kontinyu dapat digunakan untuk membantu berbagai pihak terkait dalam berbagai kebutuhan, seperti perpajakan (Pajak Bumi dan Bangunan), ganti rugi pembebasan lahan, taksiran pertanggungan kredit bank, dan sebagainya.
\end{abstract}

Kata Kunci — Nilai Jual Objek Pajak, Nilai Tanah

\section{PENDAHULUAN}

I NDONESIA merupakan negara yang memiliki luas lautan empat kali lebih besar dibanding daratan sehingga disebut sebagai negara maritim. Dengan luasnya lautan tersebut, Pemerintah Indonesia terus mengupayakan pemanfaatan laut secara lebih baik untuk kesejahteraan rakyat terutama dari segi ekonomi. Pembangunan infrastruktur seperti pelabuhan untuk mewujudkan tol laut adalah salah satu cara pemerintah untuk memanfaatkan laut.

Pembangunan Pelabuhan Internasional Kalimireng yang sedang berjalan di Kecamatan Manyar, Kabupaten Gresik adalah cara pemerintah dalam mewujudkan program tol laut. Keberadaan Pelabuhan Internasional Kalimireng menjadikan Gresik sebagai daerah yang memiliki pelabuhan besar di kawasan Asia Pasifik karena Pelabuhan Internasional Kalimireng mampu menjadi sandaran kapal-kapal besar. Dengan pembanguan Pelabuhan Internasional Kalimireng tersebut secara otomatis berpengaruh pada lingkungan sekitar karena menjadikan wilayah sekitar pelabuhan semakin strategis dengan potensi ekonomi yang cukup besar. Perlu adanya pemantauan nilai tanah secara kontinyu agar dapat mengetahui perubahan harga yang kemudian dapat digunakan untuk membantu berbagai pihak terkait dalam berbagai kebutuhan, seperti perpajakan (Pajak Bumi dan Bangunan), ganti rugi pembebasan lahan, taksiran pertanggungan kredit bank, dan sebagainya.

Oleh karena itu, pada penelitian ini dilakukan analisa perubahan nilai tanah di sekitar lokasi pembangunan Pelabuhan Internasional Kalimireng. Penelitian dilakukan di Kecamatan Manyar dan Bungah, Kabupaten Gresik yang merupakan kecamatan di sekitar pelabuhan. Metode yang digunakan adalah metode pendekatan perbandingan data pasar (sales comparison approach). Penilaian dengan metode pendekatan perbandingan data pasar (sales comparison approach) didasarkan pada mekanisme pasar (transaksi jual beli yang terjadi) dengan cara membandingkan objek lain yang sejenis yang nilai jualnya telah diketahui setelah dilakukan penyesuaian yang diperlukan [1].

\section{METODOLOGI PENELITIAN}

\section{A. Lokasi Penelitian}

Lokasi yang digunakan adalah Kabupaten Gresik, Jawa Timur. Wilayah penelitian ini meliputi, 19 Desa di Kecamatan Manyar dan 8 Desa di Kecamatan Bungah yang merupakan 
wilayah di sekitar lokasi pembangunan Pelabuhan Internasional Kalimireng. Berikut Desa yang terdapat pada Kecamatan Manyar dan Bungah yang dijadikan sebagai wilayah penelitian:

Kecamatan Manyar, antara lain:

- Desa Manyarejo

- Desa Manyar Sidorukun

- Desa Manyar Sidomukti

- Desa Sukomulyo

- Desa Banyuwangi

- Desa Peganden

- Desa Leran

- Desa Karangrejo

- Desa Betoyoguci

- Desa Betoyokauman

- Desa Sembayat

- Desa Roomo

- Desa Yosowilangun

- Desa Suci
- Desa Banjarari

- Desa Pongangan

- Desa Gumeno

Kecamatan Bungah, meliputi:

- Desa Bedanten

- Desa Tanjung Widoro

- Desa Watuagung

- Desa Kramat

- Desa Sungonlegowo

- Desa Indrodelik

- Desa Bungah

- Desa Kisik

\section{B. Rancangan Penelitian}

Tahap penelitian terdiri dari pengumpulan data, pengolahan data serta hasil dan analisa. Untuk lebih jelasnya dapat dilihat pada gambar 1 .

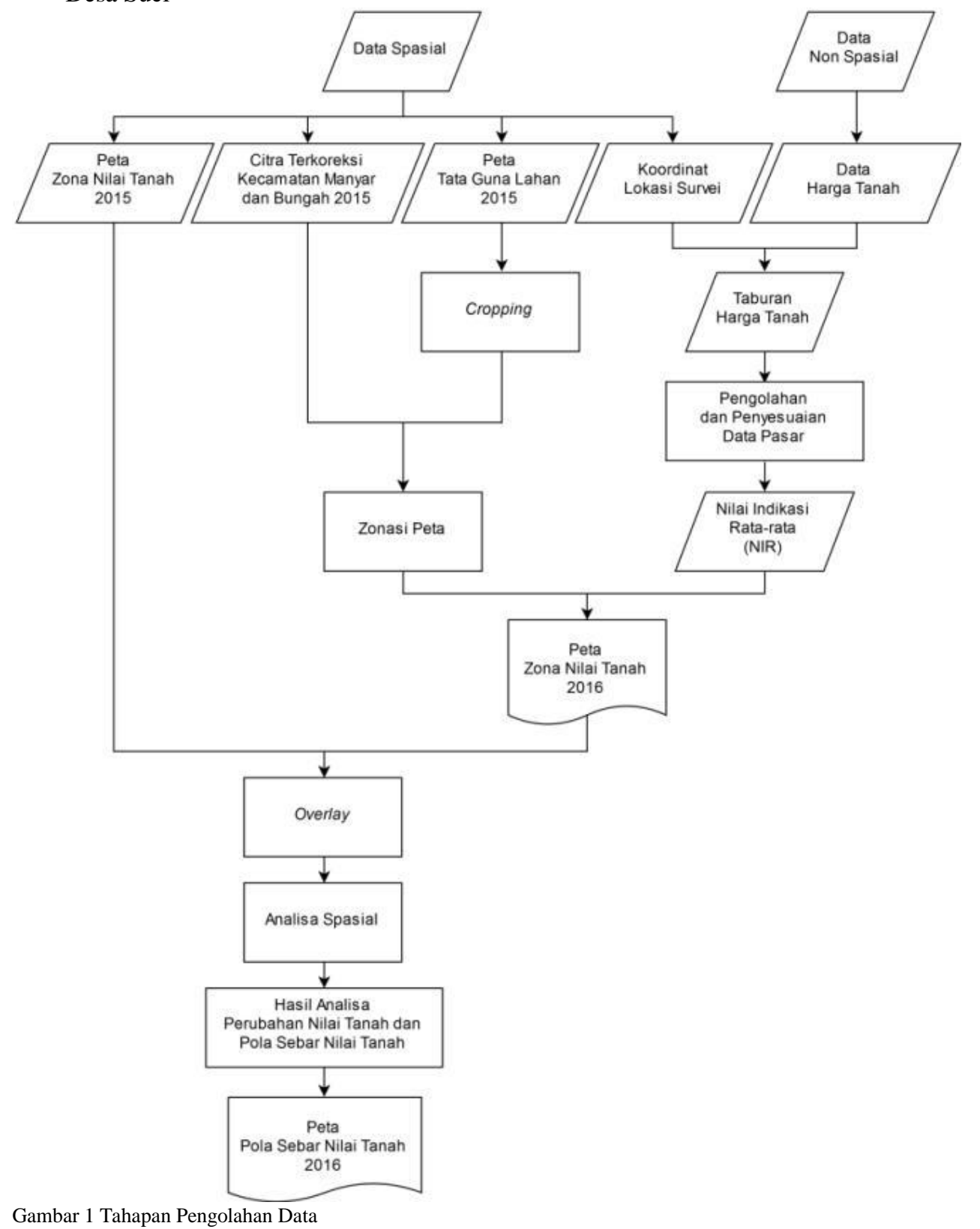




\section{Data Yang Digunakan}

Penelitian ini menggunakan data spasial berupa peta rencana tata ruang wilayah tentang penggunaan lahan tahun 2015, citra terkoreksi tahun 2014, dan koordinat lokasi survei harga tanah. Sedangkan data non spasial yang digunakan adalah data harga tanah hasil survei di lapangan dan data Nilai Jual Objek Pajak (NJOP) dari Dinas Pendapatan, Pengelolaan Keuangan dan Aset Daerah (DPPKAD) Kabupaten Gresik.

\section{Analisis Data}

Analisa hasil diperoleh dengan metode analisis spasial yakni dengan cara melakukan overlay Peta Zona Nilai Tanah 2014 Kecamatan Manyar dan Bungah dengan Peta Zona Nilai Tanah 2016 (hasil penelitian) sehingga daat dilakukan analisa perubahan nilai tanah. Kemudian, dilakukan analisa pola sebar harga tanah dengan menganalisa Peta Zona Nilai Tanah 2016 (hasil penelitian). Selain itu, sebelum melakukan overlay peta, dilakukan analisa inventarisasi data, analisa pembuatan zona, analisa penyesuaian data, dan analisa NJOP.

\section{HASIL DAN ANALISA}

Pada bagian ini akan ditampilkan hasil dari pelaksanaan penelitian yang telah dilakukan beserta analisanya. Hasil penelitian ini adalah Peta Zona Nilai Tanah (ZNT) 2016 dan Peta Pola Sebar Nilai Tanah 2016. Sedangkan, analisa dari penelitian ini adalah analisa perubahan nilai tanah dan pola sebar nilai tanah di Kecamatan Manyar dan Bungah yang merupakan wilayah sekitar lokasi pembangunan Pelabuhan Internasional Kalimireng.

\section{A. Peta Zona Nilai Tanah 2016}

Pada penelitian ini, dihasilkan Peta Zona Nilai Tanah (ZNT) Kecamatan Manyar dan Bungah 2016. Peta Zona Nilai Tanah (ZNT) 2016 ini berisi taburan nilai tanah yang dibagi dalam beberapa zona di Kecamatan Manyar dan Bungah. Terdapat 67 zona yang diklasifikasikan menurut karakteristik penggunaan lahan, meliputi pemukiman, tambak, pergudangan, dan tanah kosong. Berikut Peta Zona Nilai Tanah (ZNT) 2016 Kecamatan Manyar dan Bungah:

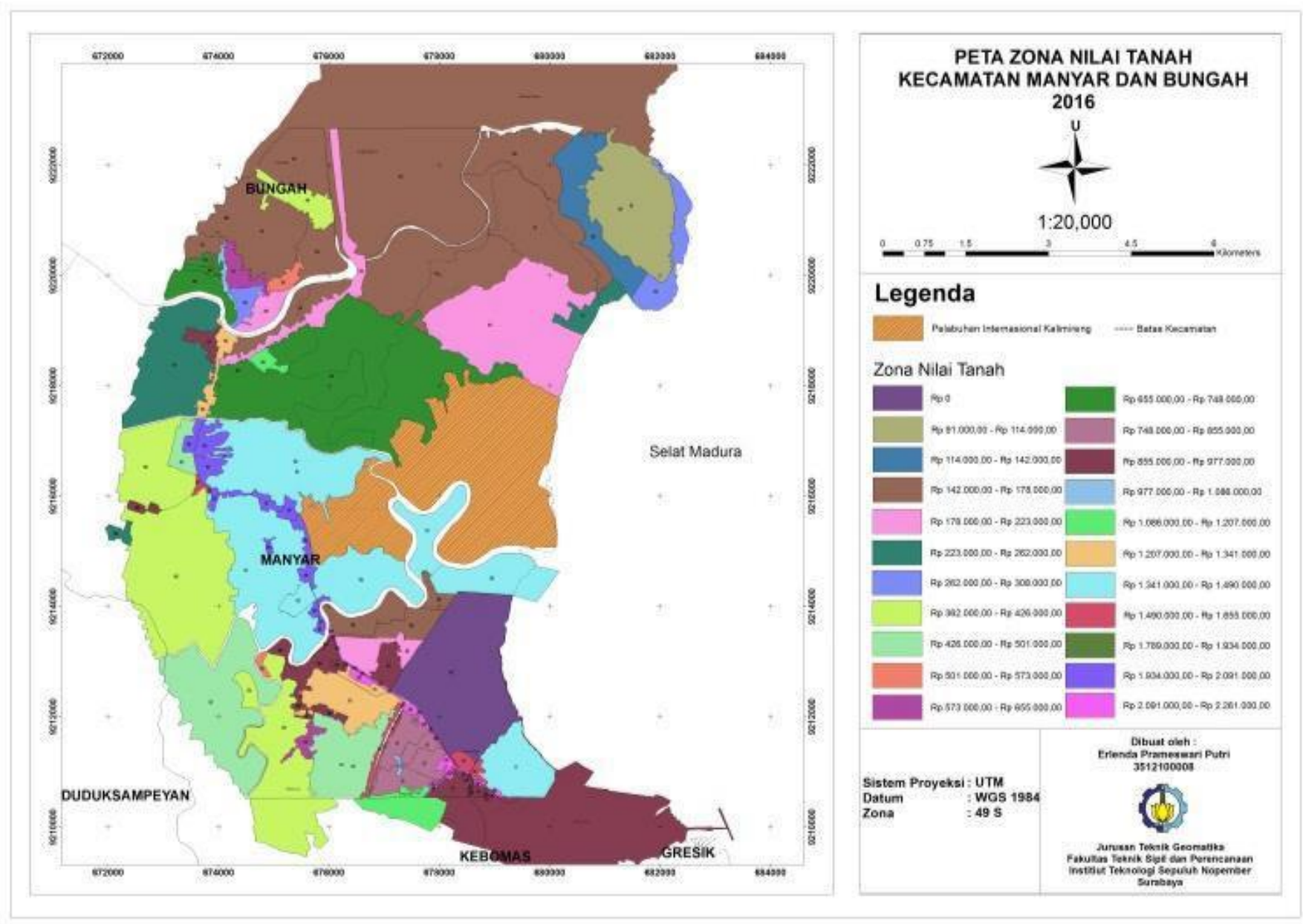

Gambar 2 Peta Zona Nilai Tanah (ZNT) 2016

\section{B. Peta Pola Sebar Nilai Tanah 2016}

peta pola sebar nilai tanah Kecamatan Manyar dan Bungah 2016 dibuat berdasarkan Nilai Indikasi Rata-Rata (NIR) 2016. Peta ini digunakan untuk mengetahui sebaran nilai tanah di wilayah Pelabuhan Internasional Kalimireng. Sebaran nilai tanah tersebut dibagi dalam 4 radius, yaitu radius $2 \mathrm{~km}, 4 \mathrm{~km}, 6$ $\mathrm{km}$, dan $8 \mathrm{~km}$ dari pelabuhan. Berikut peta pola sebar nilai tanah berdasarkan Nilai Indikasi Rata-Rata (NIR) 2016: 

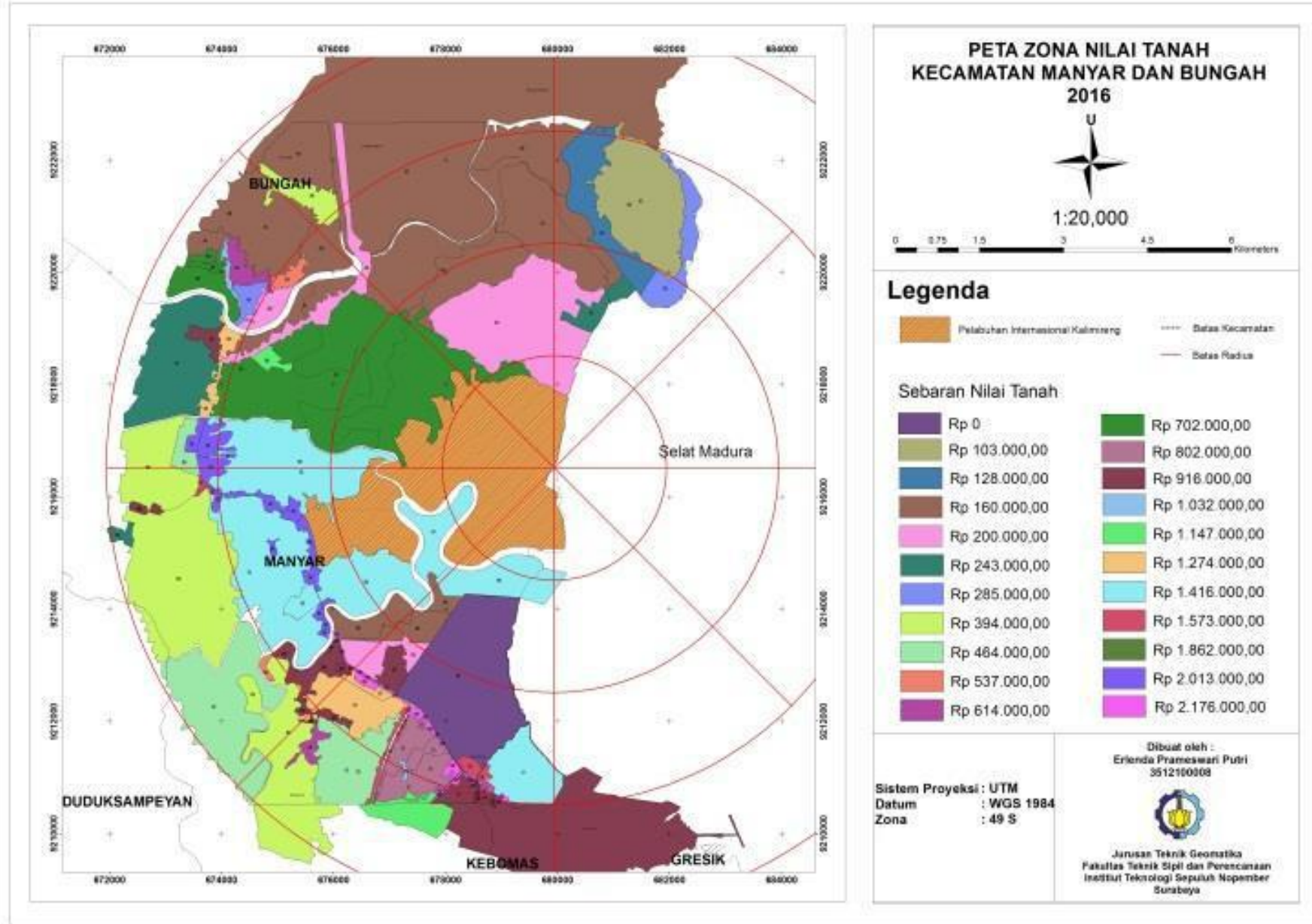

Gambar 3 Peta Pola Sebar Nilai Tanah 2016

\section{Analisa Inventarisasi Data}

Berdasarkan pengumpulan data di lapangan dengan menggunakan radius 8 kilometer didapatkan 24 desa yang menjadi wilayah studi dengan rincian 8 desa di Kecamatan Bungah dan 16 desa di Kecamatan Manyar. Pengumpulan data ini membagi wilayah studi menjadi beberapa radius, yaitu 2 kilometer, 4 kilometer, 6 kilometer, dan 8 kilometer. Berikut desa yang menjadi wilayah studi:

Tabel 1.

Wilayah studi

\begin{tabular}{|c|c|c|c|}
\hline \multicolumn{4}{|c|}{ Radius } \\
\hline $2 \mathrm{~km}$ & $4 \mathrm{~km}$ & $6 \mathrm{~km}$ & $8 \mathrm{~km}$ \\
\hline $\begin{array}{c}\text { Manyar } \\
\text { Sidorukun, } \\
\text { Manyarejo }\end{array}$ & $\begin{array}{c}\text { Manyar } \\
\text { Sidorukun, } \\
\text { Manyarejo, } \\
\text { Manyar } \\
\text { Sidomukti, } \\
\text { Kramat }\end{array}$ & $\begin{array}{l}\text { Sukomulyo, } \\
\text { Peganden, } \\
\text { Manyarejo, } \\
\text { Manyar } \\
\text { Sidomukti, } \\
\text { Banyuwangi } \\
\text { Karangrejo, } \\
\text { Bedanten, } \\
\text { Tanjung } \\
\text { Widoro, } \\
\text { Watuagung, } \\
\text { Kramat }\end{array}$ & $\begin{array}{c}\text { Romo, } \\
\text { Sukomulyo } \\
\text { Pongangan, } \\
\text { Peganden, } \\
\text { Banjarsari, } \\
\text { Leran } \\
\text { Betoyoguci, } \\
\text { Betoyokauman, } \\
\text { Gumeno, } \\
\text { Sembayat, } \\
\text { Ngampel, } \\
\text { Bungah, } \\
\text { Sukorejo, }\end{array}$ \\
\hline
\end{tabular}

Indrodelik,

Sungonlegowo,

Tanjung

Widoro

Pengumpulan data dengan menggunakan radius dilakukan untuk memudahkan pencarian data di lapangan karena wilayah studi yang cukup besar yakni radius 8 kilometer dari pelabuhan serta digunakan untuk mengklasifikasikan pola sebar nilai tanah berdasarkan radius.

\section{Analisa Pembuatan Zona}

Pembuatan zona menghasilkan 67 zona pada studi wilayah. Zona tersebut dibagi berdasarkan karakteristik dan lingkungan antara lain, jenis penggunaan lahan, kedudukan tanah seperti letak tanah, dan kedudukan terhadap jalan. Dalam setiap zona diambil minimal 3 data pasar sebagai sampling sesuai dengan ketentuan MAPPI (Masyarakat Profesi Penilai Indonesia). Pembuatan zona dibuat tidak berdasar batas desa sedangkan zona lama dari data DPPKAD dibuat per desa. Berikut hasil pembuatan zona:

Tabel 2.

Deskripsi penggunaan lahan

\begin{tabular}{ll}
\hline \hline Zona & Deskripsi Penggunaan Lahan \\
\hline AA & Tambak \\
AB & Tambak \\
AC & Tambak \\
\hline \hline
\end{tabular}




\begin{tabular}{|c|c|}
\hline $\mathrm{AD}$ & Tambak \\
\hline $\mathrm{AE}$ & Tambak \\
\hline $\mathrm{AF}$ & Pemukiman \\
\hline AG & Tambak (Pesisir) \\
\hline $\mathrm{AH}$ & Kebun, tambak kering, tanah kosong \\
\hline AI & Tambak \\
\hline $\mathrm{AJ}$ & Tambak \\
\hline $\mathrm{AK}$ & Pemukiman \\
\hline $\mathrm{AL}$ & Tambak \\
\hline $\mathrm{AM}$ & Pemukiman \\
\hline $\mathrm{AN}$ & Pemukiman \\
\hline $\mathrm{AO}$ & Pemukiman \\
\hline AP & Pemukiman \\
\hline AQ & Pemukiman \\
\hline AR & Tambak, tanah kosong, dan pemukiman \\
\hline AS & Tambak \\
\hline AT & Tambak (Pesisir) \\
\hline AU & Tambak \\
\hline AV & Tambak \\
\hline AW & Tambak \\
\hline $\mathrm{AX}$ & Tambak \\
\hline AY & Tambak \\
\hline $\mathrm{AZ}$ & Pemukiman \\
\hline $\mathrm{BA}$ & Pemukiman \\
\hline $\mathrm{BB}$ & Pemukiman \\
\hline $\mathrm{BC}$ & Pemukiman \\
\hline $\mathrm{BD}$ & Tambak \\
\hline $\mathrm{BE}$ & Pemukiman dan tambak \\
\hline $\mathrm{BF}$ & $\begin{array}{l}\text { Tambak, pergudangan, pemukiman } \\
\text { (pinggir jalan) }\end{array}$ \\
\hline BG & Tambak \\
\hline $\mathrm{BH}$ & Tambak \\
\hline $\mathrm{BI}$ & Pemukiman \\
\hline $\mathrm{BJ}$ & Tambak \\
\hline BK & Pemukiman \\
\hline $\mathrm{BL}$ & Tambak dan tanah kosong \\
\hline $\mathrm{BM}$ & Pemukiman \\
\hline $\mathrm{BN}$ & Pemukiman dan tambak \\
\hline $\mathrm{BO}$ & Tambak \\
\hline $\mathrm{BP}$ & Pergudangan \\
\hline BQ & Tambak \\
\hline $\mathrm{BR}$ & Tambak (pinggir pelabuhan/pesisir) \\
\hline BS & Tambak dan tanah kosong \\
\hline BT & Tambak \\
\hline BU & Tanah urugan (rencana perumahan) \\
\hline BV & Pemukiman dan tambak \\
\hline BW & Tanah kosong dan tambak \\
\hline BX & Tambak \\
\hline BY & Maspion \\
\hline $\mathrm{BZ}$ & Pemukiman \\
\hline $\mathrm{CA}$ & Pemukiman, tambak, dan tanah kosong \\
\hline $\mathrm{CB}$ & Pemukiman \\
\hline $\mathrm{CC}$ & Tambak kering dan tanah kosong \\
\hline $\mathrm{CD}$ & Pemukiman \\
\hline $\mathrm{CE}$ & $\begin{array}{l}\text { Tambak dan tanah kosong (pinggir jalan } \\
\text { tol) }\end{array}$ \\
\hline $\mathrm{CF}$ & Tanah kosong \\
\hline CG & Pemukiman (perumahan) \\
\hline $\mathrm{CH}$ & Tambak \\
\hline CI & Tambak \\
\hline CJ & Tambak \\
\hline $\mathrm{CK}$ & Pergudangan \\
\hline $\mathrm{CL}$ & Pemukiman \\
\hline $\mathrm{CM}$ & $\begin{array}{l}\text { Pemukiman, tambak, dan tanah kosong } \\
\text { (pinggir jalan) }\end{array}$ \\
\hline $\mathrm{CN}$ & Pergudangan \\
\hline $\mathrm{CO}$ & Pemukiman \\
\hline
\end{tabular}

\section{E. Analisa Penyesuaian Data}

Penyesuaian data dilakukan untuk menyesuaikan data harga tanah yang diambil di lapangan menjadi nilai tanah yang sesuai atau biasa disebut Nilai Indikasi Rata-Rata (NIR). Metode yang digunakan dalam penyesuaian data ini adalah metode pendekatan perbandingan harga pasar. Ada 10 macam penyesuaian yang harus dilakukan untuk menghasilkan NIR, antara lain: penyesuaian jenis data, sumber data, jenis penggunaan, kontur, elevasi terhadap jalan, bentuk, luas, kedudukan tanah, status tanah, dan waktu. Dalam pengerjaan proses penyesuaian data ini didasarkan pada opini, namun tetap harus dapat dipertanggungjawabkan kebenarannya. Oleh karena itu, proses ini dibimbing langsung oleh salah satu anggota MAPPI.

\section{F. Analisa Nilai Jual Objek Pajak (NJOP)}

Setelah dilakukan penyesuain harga tanah, maka NIR dapat diklasifikasikan menurut Peraturan Menteri Keuangan Nomor 150/Pmk.03/2010 Tentang Klasifikasi dan Penetapan Nilai Jual Objek Pajak Sebagai Dasar Pengenaan Pajak Bumi dan Bangunan. Hasilnya, terdapat 21 klas pada Peta ZNT 2016 dengan rentang nilai tanah adalah $\mathrm{Rp} 91.000,00-\mathrm{Rp}$ 114.000,00 (kelas 079) sampai dengan Rp 2.091.000,00 - Rp 2.261.000,00 (kelas 057), kecuali kelas 060 dan 073. Berikut rincian kelas yang ada dalam NJOP 2016:

Tabel 3.

Klasifikasi zona berdasarkan NJOP

\begin{tabular}{|c|c|c|}
\hline Kelas & Pengelompokan Nilai Jual Bumi $\left(\mathrm{Rp} / \mathrm{m}^{2}\right)$ & Zona \\
\hline 057 & $2.091 .000,00 \mathrm{~s} / \mathrm{d} 2.261 .000,00$ & $\mathrm{CM}$ \\
\hline 058 & $1.934 .000,00 \mathrm{~s} / \mathrm{d} 2.091 .000,00$ & $\mathrm{BE}, \mathrm{BF}, \mathrm{BK}$ \\
\hline 059 & $1.789 .000,00 \mathrm{~s} / \mathrm{d} 1.934 .000,00$ & $\mathrm{BP}$ \\
\hline 060 & $1.655 .000,00 \mathrm{~s} / \mathrm{d} 1.789 .000,00$ & \\
\hline 061 & $1.490 .000,00 \mathrm{~s} / \mathrm{d} 1.655 .000,00$ & $\mathrm{BI}, \mathrm{CE}, \mathrm{CH}$ \\
\hline 062 & $1.341 .000,00 \mathrm{~s} / \mathrm{d} 1.490 .000,00$ & $\begin{array}{c}\mathrm{BD}, \mathrm{BJ}, \mathrm{BL}, \mathrm{BQ}, \mathrm{BR}, \\
\mathrm{CI}, \mathrm{CJ}\end{array}$ \\
\hline 063 & $1.207 .000,00 \mathrm{~s} / \mathrm{d} 1.341 .000,00$ & $\mathrm{BA}$ \\
\hline 064 & $1.086 .000,00 \mathrm{~s} / \mathrm{d} 1.207 .000,00$ & $\mathrm{BB}$ \\
\hline 065 & $977.000,00 \mathrm{~s} / \mathrm{d} 1.086 .000,00$ & $\mathrm{AO}, \mathrm{CG}$ \\
\hline 066 & $855.000,00 \mathrm{~s} / \mathrm{d} 977.000,00$ & $\begin{array}{c}\mathrm{AZ}, \mathrm{BC}, \mathrm{BM}, \mathrm{BS}, \mathrm{BW}, \\
\mathrm{BX}, \mathrm{BZ}, \mathrm{CK}, \mathrm{CL}, \mathrm{CO}, \\
\mathrm{CN}\end{array}$ \\
\hline 067 & $748.000,00 \mathrm{~s} / \mathrm{d} 855.000,00$ & $\mathrm{CF}$ \\
\hline 068 & $655.000,00 \mathrm{~s} / \mathrm{d} 748.000,00$ & $\mathrm{AN}, \mathrm{AU}, \mathrm{CD}$ \\
\hline 069 & $573.000,00 \mathrm{~s} / \mathrm{d} 655.000,00$ & $\mathrm{AM}, \mathrm{AP}, \mathrm{CA}, \mathrm{CB}$ \\
\hline 070 & $501.000,00 \mathrm{~s} / \mathrm{d} 573.000,00$ & $\mathrm{AQ}, \mathrm{BU}$ \\
\hline 071 & $426.000,00 \mathrm{~s} / \mathrm{d} 501.000,00$ & $\mathrm{BG}, \mathrm{BT}, \mathrm{CC}$ \\
\hline 072 & $362.000,00 \mathrm{~s} / \mathrm{d} 426.000,00$ & $\mathrm{AK}, \mathrm{BH}, \mathrm{BO}, \mathrm{BV}$ \\
\hline 073 & $308.000,00 \mathrm{~s} / \mathrm{d} 362.000,00$ & \\
\hline 074 & $262.000,00 \mathrm{~s} / \mathrm{d} 308.000,00$ & AG, AX \\
\hline 075 & $223.000,00 \mathrm{~s} / \mathrm{d} 262.000,00$ & AT, AY, BN \\
\hline 076 & $178.000,00 \mathrm{~s} / \mathrm{d} 223.000,00$ & $\mathrm{AB}, \mathrm{AS}, \mathrm{AW}$ \\
\hline 077 & $142.000,00 \mathrm{~s} / \mathrm{d} 178.000,00$ & $\begin{array}{c}\mathrm{AA}, \mathrm{AC}, \mathrm{AI}, \mathrm{AJ}, \mathrm{AL}, \\
\mathrm{AR}, \mathrm{AV}\end{array}$ \\
\hline 078 & $114.000,00 \mathrm{~s} / \mathrm{d} 142.000,00$ & $\mathrm{AD}, \mathrm{AE}$ \\
\hline 079 & $91.000,00 \mathrm{~s} / \mathrm{d} 114.000,00$ & $\mathrm{AF}, \mathrm{AH}$ \\
\hline
\end{tabular}

Setelah dilakukan klasifikasi, Zona dengan NJOP tertinggi adalah CM. Zona CM merupakan zona yang dibentuk dari sisi kanan dan kiri Jalan Raya Sembayat-Gresik. Jalan Raya Sembayat-Gresik adalah akses utama transportasi darat yang dilalui kendaraan menuju pusat kota. Sedangkan, zona dengan 
NJOP terendah adalah AF dan AH. Zona AF dan AH adalah zona yang terletak di Desa Watuagung dan Kramat, Kecamatan Bungah. Untuk zona yang berada di sekitar Pelabuhan Internasional Kalimireng memiliki NJOP tinggi yaitu, urutan kelima teratas. Zona-zona tersebut berada dalam radius 2 kilometer dari pintu masuk pelabuhan. Zona tersebut antara lain, zona BD, BE, BF, BJ, BK, BL, BP, BQ, dan BR.

\section{G. Analisa Perubahan Nilai Tanah}

Berdasarkan dari hasil pengumpulan data koordinat lokasi survei harga tanah dan data taburan harga tanah yang telah dilakukan pengolahan, menghasilkan Peta Zona Nilai Tanah (ZNT) 2016. Kemudian, dilakukan analisa spasial dengan overlay Peta ZNT 2016 dengan Peta ZNT 2014. Dari hasil analisa spasial dengan overlay peta, didapatkan hasil analisa perubahan nilai tanah pada masing-masing zona beserta persentase perubahannya. Berdasar hasil analisa yang telah diperoleh, wilayah sekitar Pelabuhan Internasional Kalimireng mengalami kenaikan yang signifikan, yakni: zona BD (323\%), BE (150\%), BF (95\%), BJ (1006\%), BK (151\%), BL (164\%), BP (102\%), BQ (323\%), dan BR (1006\%). Zona-zona tersebut memiliki nilai tanah paling tinggi, yakni Rp 1.341.000,00 s/d Rp 2.091.000,00. Pada Zona Nilai Tanah (ZNT) Lama, zonazona tersebut memiliki nilai tanah $\mathrm{Rp} 128.000,00 \mathrm{~s} / \mathrm{d} \mathrm{Rp}$ 1.032.000,00.

\section{H. Analisa Pola Sebar Nilai Tanah}

Analisa ini dilakukan dengan cara membuat radius sejauh 8 $\mathrm{km}$ dari dermaga pelabuhan. Radius tersebut dibagi menjadi 4 , yaitu 2 km, 4 km, 6 km, dan 8 km. Kemudian dibagi menjadi berdasarkan arah mata angin. Hasil dari analisa ini adalah pada karakteristik lahan tambak, kebun, dan tanah kosong semakin jauh dari pelabuhan nilai tanah semakin rendah, namun hal ini tidak berlaku pada karakteristik lahan pemukiman dan pergudangan. Hal ini terjadi karena, pada wilayah pemukiman dan pergudangan lebih banyak faktor yang mempengaruhi nilai tanah.

\section{KESIMPULAN}

Dari penelitian ini dapat diambil beberapa kesimpulan, yaitu:

1. Terdapat 67 zona nilai tanah yang diklasifikasikan menurut karakteristik penggunaan lahan, meliputi pemukiman, tambak, pergudangan, dan tanah kosong. Zona nilai tanah memiliki kode AA hingga CO. Rentang zona nilai tanah pada wilayah studi ini adalah $\mathrm{Rp}$ 91.000,00 - Rp 114.000,00 sampai dengan Rp. 2.091.000,00 - Rp 2.261.000,00. Zona dengan nilai tanah tertinggi adalah CM. CM merupakan zona yang terletak di sisi kanan dan kiri Jalan Raya Sembayat-Gresik. Sedangkan, zona dengan nilai tanah terendah adalah AF dan AH. Zona tersebut berada di Desa Kramat. Untuk zona yang berada di sekitar Pelabuhan Internasional Kalimireng memiliki nilai tanah tinggi yaitu, urutan kelima teratas dari klasifikasi NJOP. Zona-zona tersebut berada dalam radius 2 kilometer dari pintu masuk pelabuhan. Zona tersebut antara lain, zona $\mathrm{BD}, \mathrm{BE}, \mathrm{BF}, \mathrm{BJ}, \mathrm{BK}, \mathrm{BL}$, $\mathrm{BP}, \mathrm{BQ}$, dan BR.
2. Perubahan nilai tanah di wilayah sekitar Pelabuhan Internasional Kalimireng mengalami kenaikan yang signifikan, yakni: zona BD wilayah tambak (323\%), BE wilayah pemukiman (150\%), BF wilayah sisi kanan dan kiri Jalan Raya Sembayat-Gresik (95\%), BJ wilayah tambak (1006\%), BK wilayah pemukiman (151\%), BL wilayah tambak dan tanah kosong (164\%), BP wilayah pergudangan (102\%), BQ wilayah tambak (323\%), dan BR wilayah tambak (1006\%). Zona-zona tersebut memiliki nilai tanah tinggi, yakni Rp 1.341.000,00 s/d Rp 2.091.000,00. Pada Zona Nilai Tanah (ZNT) Lama, zonazona tersebut memiliki nilai tanah $\mathrm{Rp} 128.000,00 \mathrm{~s} / \mathrm{d} \mathrm{Rp}$ 1.032.000,00.

3. Pola sebar harga tanah pada wilayah studi menunjukkan bahwa semakin jauh dari pelabuhan maka nilai tanah semakin rendah, begitu pula sebaliknya. Namun, hal ini hanya berlaku untuk karakteristik berupa tambak. Untuk pemukiman, hal tersebut tidak berlaku dikarenakan banyak faktor lain yang mempengaruhi nilai tanahnya.

\section{SARAN}

1. Perlu dilakukan pemantauan nilai tanah secara kontinyu sebagai salah satu cara mengendalikan nilai tanah terutama pada wilayah yang mengalami perubahan penggunaan lahan seperti Pelabuhan Internasional Kalimireng.

2. Pada saat melakukan pengumpulan data harga tanah di lapangan, sebaiknya dilakukan sosialisasi terlebih dahulu atau mendapatkan pendampingan dari pihak pemerintahan, seperti staf desa.

\section{DAFTAR PUSTAKA}

[1] Hidayati, W., Harjanto, B. 2003. Konsep Dasar Penilaian Properti. Yogyakarta: BPFE.

[2] Triatmodjo, Bambang. 2009. Perencanaan Pelabuhan. Yogyakarta: Beta Offset. 